\title{
Multi-Drug Resistant Acinetobacter: Detection of blaNDM-1 genotype and biofilm formation at a tertiary care hospital in Eastern Nepal
}

\author{
Manisha Kumari \\ B. P. Koirala Institute of Health Sciences \\ Narayan Raj Bhattarai ( $\sim$ bhattarai03@yahoo.com ) \\ B. P. Koirala Institute of Health Sciences \\ Keshav Rai \\ B. P. Koirala Institute of Health Sciences \\ Tejendra Pandit \\ B. P. Koirala Institute of Health Sciences \\ Basudha Khanal \\ B. P. Koirala Institute of Health Sciences
}

\section{Research article}

Keywords: Acinetobacter, Antimicrobial resistance, biofilm, Extended-spectrum beta-lactamases, Metallo-beta-lactamases, blaNDM-1.

Posted Date: March 10th, 2020

DOI: https://doi.org/10.21203/rs.3.rs-16503/v1

License: @) (7) This work is licensed under a Creative Commons Attribution 4.0 International License. Read Full License 


\section{Abstract}

Background: Acinetobacter species is an important hospital acquired pathogen. Rapid development of resistance to multiple drug and ability to form biofilm make these bacteria more adaptable to survive in health care facilities, thus posing a challenge for its effective management. This study was aimed to characterize clinical isolates of Acinetobacter spp, study their antimicrobial susceptibility pattern and ability to form biofilm. Resistant Acinetobacter was further analyzed for the detection of extended spectrum $\beta$-lactamases (ESBLs), metallo $\beta$-lactamases (MBLs) production and presence of blaNDM-1 (New Delhi metallo-beta-lactamase-1) gene.

Results: A total of 324 Acinetobacter species isolated from various clinical specimens submitted to Department of Microbiology, B. P. Koirala Institute of Health Sciences, Dharan, were studied Antibiotic susceptibility testing, detection of ESBL and MBL production, and biofilm formation was performed by standard microbiological methods. PCR was done to determine the presence of blaNDM-1 gene.

Predominant Acinetobacter species isolated was A calcoaceticus-baumannii Complex (Acb complex) 167 (51.5\%). 13 (4.0\%) were ESBL producers, 61.9\% (70/113) were MBL, $10.6 \%$ (12/113) were carbapenemase producers. About 40\% were Multi-drug resistant (MDR). Among MDR, producers of ESBL, MBL and carbapenemase were $1.6 \%, 57 \%$ and $9.6 \%$, respectively. Thirty seven percent isolates formed biofilm. A significant proportion of biofilm producers were MDR $(p<0.001)$. Majority was resistant to cefotaxime $(73.8 \%)$ and cefepime $(74.4 \%)$. blaNDM1 gene was present in 33 isolates.

Conclusions: Resistant Acinetobacter formed a substantial proportion in our hospital with presence of blaNDM-1 gene in significant numbers. A matter of great concern is association of Multi-drug resistant phenotype with biofilm formation. This situation warrants a stringent surveillance and adherence to Infection prevention and control practice.

\section{Background}

Acinetobacter, a widely distributed, saprophytic bacterium in nature has established itself as the most common nosocomial pathogen [1,2]. Although different species of Acinetobacter have potential to cause infection, $80 \%$ of infections are caused by Acinetobacter baumannii. Ease of survival even in adverse environment, ability to form biofilms on the surfaces and possession of many genes for antimicrobials resistance have made this bacteria an important pathogen. The potential ability to form biofilms, indeed, could explain outstanding antibiotic resistance and survival properties in the harsh environment of hospital, particularly the intensive care setting [3,4].

Over the past few decades, its clinical importance has been increased by its ability to receive antimicrobial resistance factors [5] through the transfer of plasmid or transposons that contain antimicrobial resistant genes particularly in hospital setting where usage of antibiotics is huge leading to selective pressure. Multi-drug resistant (MDR) Acinetobacter species is defined as the isolate resistant to at least three classes of antimicrobial agents - all penicillins and cephalosporins, fluoroquinolones, and aminoglycosides [6]. These strains are implicated in variety of life threatening infections such as ventilatorassociated pneumonia (VAP), urinary tract infections, blood stream infections, surgical site infections, and infections associated with medical devices occurring especially in patients in intensive care unit. Moreover, significant correlation between biofilm formation and multi-drug resistance has been attributed to the threat imposed by Acinetobacter to the current antibiotic era [7].

Diagnosis of multi-drug resistant Acinetobacter infections is a great challenge owing to the distribution of various species in relation to the type of infection, their antimicrobial profile and biofilm forming phenotype. Hence, it is crucial to minimize the risk associated with Acinetobacter infection in health care facilities, from effective management and infection control perspectives. Present study was conducted to characterize the clinical Acinetobacter isolates with special reference to the detection of antimicrobial resistance, biofilm formation and presence of bla $\mathrm{NDM}_{-1}$ (New Delhi metallo-beta-lactamase-1) gene.

\section{Results}

Among 324 isolates of Acinetobacter, 167 (51.5\%) were Acinetobacter calcoaceticus-baumannii complex (Acb complex) followed by 83 (25.6\%) A. lowffi, 38 (11.7\%) A. haemolyticus, 30 (9.3\%) A. radioresistens and 6 (1.9\%) A. junii.

Among the different specimens analyzed, frequency of yield of Acinetobacter from blood in the descending order of frequency was A. haemolyticus (37\%), A. lowffi (33\%), A. radioresistens (30\%), Acb complex (20\%), and A. junii (16.5\%), as shown in Table 1. In case of pus samples, Acb complex was predominant (37\%), whereas from urine sample it was A. radioresistens (33\%). In this study, $26 \%$ of the samples were obtained from medical ward, $20 \%$ from ICU, $11 \%$ from surgery and pediatrics, $6 \%$ from gynecology, $12 \%$ were from OPD, $4 \%$ were from emergency, NICU and orthopedic department. Acb complex was predominant in ICU (76.7\%). 
Table 1

Acinetobacter species from different clinical samples $(n=324)$

\begin{tabular}{|lllllll|}
\hline Specimen types & $\begin{array}{l}\text { Acb complex } \\
\mathbf{n = 1 6 7 ( 5 1 \% )}\end{array}$ & $\begin{array}{l}\text { A. lowffi } \\
\mathbf{n = 8 3 ( 2 6 \% )}\end{array}$ & $\begin{array}{l}\text { A. haemolyticus } \\
\mathbf{n = 3 8 ( 1 2 \% )}\end{array}$ & $\begin{array}{l}\text { A. radioresistens } \\
\mathbf{n = 3 0}(\mathbf{9} \%)\end{array}$ & $\begin{array}{l}\text { A. junii } \\
\mathbf{n = 6}(\mathbf{2} \%)\end{array}$ & Total \\
\hline Blood & $33(20 \%)$ & $27(33 \%)$ & $14(37 \%)$ & $9(30 \%)$ & $1(16.5 \%)$ & $84(26 \%)$ \\
\hline Pus & $61(37 \%)$ & $11(13 \%)$ & $3(8 \%)$ & $6(20 \%)$ & $1(16.5 \%)$ & $82(25 \%)$ \\
\hline Urine & $15(9 \%)$ & $17(20 \%)$ & $6(16 \%)$ & $10(33 \%)$ & $1(16.5 \%)$ & $49(15 \%)$ \\
\hline Sputum & $12(7 \%)$ & $3(4 \%)$ & $3(8 \%)$ & $2(7 \%)$ & - & $20(6 \%)$ \\
\hline Endotracheal aspirate & $31(18 \%)$ & $2(2 \%)$ & $2(5 \%)$ & $2(7 \%)$ & - & $37(11 \%)$ \\
\hline Exudate body fluid & $6(3 \%)$ & $12(14 \%)$ & $1(2 \%)$ & - & $2(33 \%)$ & $21(6.2 \%)$ \\
\hline Central venous catheter & $3(2 \%)$ & $2(2 \%)$ & $4(10 \%)$ & - & - & $9(3 \%)$ \\
\hline CSF & $3(2 \%)$ & $1(1 \%)$ & $3(8 \%)$ & - & - & $7(2 \%)$ \\
\hline HVS & - & $2(2 \%)$ & $1(2 \%)$ & $1(3 \%)$ & - & $4(2 \%)$ \\
\hline Nasal swab & $1(0.5 \%)$ & $4(5 \%)$ & 0 & - & $1(16.5 \%)$ & $7(1 \%)$ \\
\hline Tissue & $1(0.5 \%)$ & - & $1(2 \%)$ & - & - & $2(0.6 \%)$ \\
\hline Semen & - & $2(2 \%)$ & $1(2 \%)$ & - & - & $3(1 \%)$ \\
\hline Note: CSF = Cerebrospinal fluid, HVS = High vaginal swab & & & \\
\hline
\end{tabular}

\section{Antimicrobial Susceptibility Testing}

Resistance percentage of Acinetobacter in the descending order of frequency were cefepime $74.4 \%$ cefotaxime $73.8 \%$, ceftriaxone $65.7 \%$, ceftazidime $72.5 \%$, ceftazidime + calvulanic acid $72.2 \%$, piperacillin $65.7 \%$ ampicillin + sulbactam $36.7 \%$, amikacin $44.7 \%$, ciprofloxacin $50 \%$, and imipenem $35.2 \%$, as shown in Table 2. Acb complex was found to have had highest drug resistant phenotypes to analyzed antibiotics with $84.2 \%$ being resistant to imipenem. Acinetobacter isolates from ICU were comparatively resistant to the antibiotics than those from other wards (Fig. 1).

Table 2

Antibiotic resistance profile in of t Acinetobacter species.

\begin{tabular}{|llllll|}
\hline Antibiotics & Acb complex & A. Iwoffii & A. hemolyticus & A. junii & A. radioresistens \\
\hline $\begin{array}{l}\text { Amikacin } \\
(n=145)\end{array}$ & $117(80.7 \%)$ & $9(6.2 \%)$ & $12(8.3 \%)$ & $1(0.7 \%)$ & $6(4.1 \%)$ \\
\hline \begin{tabular}{l} 
Ampicillin + sulbactam $(n=119)$ \\
\hline $\begin{array}{l}\text { Ceftriaxone } \\
(n=213)\end{array}$
\end{tabular} & $97(81.5 \%)$ & $4(3.4 \%)$ & $11(9.2 \%)$ & $1(0.8 \%)$ & $6(5.0 \%)$ \\
\hline $\begin{array}{l}\text { Cefotaxime } \\
(n=239)\end{array}$ & $147(69.0 \%)$ & $23(10.8 \%)$ & $29(13.6 \%)$ & $2(0.9 \%)$ & $12(5.6 \%)$ \\
\hline $\begin{array}{l}\text { Cefepime } \\
(n=241)\end{array}$ & $157(65.7 \%)$ & $32(13.4 \%)$ & $31(13.0 \%)$ & $2(0.8 \%)$ & $17(7.1 \%)$ \\
\hline $\begin{array}{l}\text { Ceftazidime } \\
(n=235)\end{array}$ & $155(64.3 \%)$ & $35(14.5 \%)$ & $30(12.4 \%)$ & $3(1.2 \%)$ & $18(7.5 \%)$ \\
\hline $\begin{array}{l}\text { Ceftazidime+Clavulanic acid } \\
(n=234)\end{array}$ & $149(63.7 \%)$ & $35(15.0 \%)$ & $30(12.8 \%)$ & $2(0.9 \%)$ & $18(7.7 \%)$ \\
\hline $\begin{array}{l}\text { Ciprofloxacin } \\
(n=162)\end{array}$ & $127(78.4 \%)$ & $16(9.9 \%)$ & $11(6.8 \%)$ & $1(0.6 \%)$ & $7(4.3 \%)$ \\
\hline $\begin{array}{l}\text { Piperacillin } \\
(n=213)\end{array}$ & $143(67.1 \%)$ & $29(13.6 \%)$ & $25(11.7 \%)$ & $3(1.4 \%)$ & $13(6.1 \%)$ \\
\hline $\begin{array}{l}\text { Imipenem } \\
(n=114)\end{array}$ & $96(84.2 \%)$ & $5(4.4 \%)$ & $9(7.9 \%)$ & $1(0.9 \%)$ & $3(2.6 \%)$ \\
\hline
\end{tabular}

Among 324 isolates, 128 (39.5\%) MDR. Most of MDR were from patients in ICU 60.3\% followed by OPD 43.5\%, Ward 32.1\% and Emergency 20.0\%. Acb complex had the highest rate of MDR phenotype. 
Table 3

Acinetobacter species in relation to various type of resistant mechanism and biofilm formation

\begin{tabular}{|c|c|c|c|c|c|}
\hline Characteristic of isolates & Acb complex $(n=167)$ & A. lowffi $(n=83)$ & A. haemolyticus $(n=38)$ & A. radioresistens $(n=30)$ & A. junii $(n=6)$ \\
\hline $\operatorname{MDR}(n=128)$ & $111(86.7 \%)$ & $4(3.1 \%)$ & $8(6.3 \%)$ & $4(3.1 \%)$ & $1(0.8 \%)$ \\
\hline $\operatorname{ESBL}(n=13)$ & $10(76.9 \%)$ & - & $1(7.7 \%)$ & $2(15.4 \%)$ & - \\
\hline Carbapenemase $(n=12)$ & $10(83.3 \%)$ & - & $2(16.7 \%)$ & - & - \\
\hline $\operatorname{MBL}(n=70)$ & $56(80.0 \%)$ & $3(4.3 \%)$ & $7(10.0 \%)$ & $3(4.3 \%)$ & $1(1.4 \%)$ \\
\hline bla $_{N D M-1}$ genotype $(n=33)$ & $28(84.8 \%)$ & $2(6.1 \%)$ & $2(6.1 \%)$ & - & $1(3.0 \%)$ \\
\hline Biofilm $(n=121)$ & $94(77.7 \%)$ & $12(9.9 \%)$ & $8(6.6 \%)$ & $6(5.0 \%)$ & $1(0.8 \%)$ \\
\hline
\end{tabular}

bla ${ }_{\mathrm{NDM}-1}$ gene was detected in $45.8 \%$ (33/72) isolates. bla $\mathrm{NDM}-1_{1}$ was present mostly in Acb complexes (84.8\%) followed by A. haemolyticus (6.6\%), A. lowffi (6.1\%), and A. junii (3\%). Of all the isolates carrying the from various specimens $64.3 \%$ isolates from pus, $62.5 \%$ from blood, all from CSF ,42.9\% from ET tube aspirate, $33.3 \%$ from ascitic fluid and $20 \%$ from urine had bla $\mathrm{NDM}-1_{1}$ gene whilst it was not present in any of the Acinetobacter isolated from sputum and other body fluids. All 33 bla $_{\mathrm{NDM}-1}$ producers of this study were completely resistant. About half $50.8 \%$ of MDR Acinetobacter isolates were MBL producer and $24.2 \%$ had bla $\mathrm{NDM}_{-1}$ gene.

\section{Biofilm formation}

Among 324 isolates, biofilm production was detected in 121 (37.3\%) isolates. Forty-five (37.2\%) biofilm forming isolates were obtained from device, 36 (29.8\%) from pus, 20 (16.5\%) from blood, 18 (14.9\%) from urine and 7 (5.8\%) from sputum. Biofilm production was found highest in Acb complex (77.7\%) followed by A. lowffi (9.9\%), A. haemolyticus (6.6\%), A. radioresistens (5.0\%), A. Junii (0.8\%), as depicted in Table 3. About 60.3\% MDR and 64.4\% biofilm forming isolates were from ICU. Moreover, MDR phenotype and biofilm formation phenotypes were significantly associated ( $p$-value $<0.0001$ ) whereas no association was determined among other virulence phenotypes such as ESBL, MBL, carbapenemase, bla ${ }_{N D M}-1$, as shown in Table 4 \& Table 5 . The biofilm formations were consistently found in isolates from ICU (Fig. 2) and Acb complex (Fig. 3) as shown by principle component analysis.

Table 4

Virulence factors and biofilm formation in Acinetobacter isolates.

\begin{tabular}{|c|c|c|c|c|c|c|c|}
\hline \multicolumn{2}{|c|}{ Characteristics of isolates } & \multicolumn{4}{|l|}{ Biofilm } & \multirow[t]{2}{*}{ Total } & \multirow[t]{2}{*}{ P-value } \\
\hline & & Non Adherent & Weakly Adherent & Moderately Adherent & Strong Adherent & & \\
\hline \multirow[t]{2}{*}{ MDR } & Non-MDR & $154(47.5 \%)$ & $33(10.2 \%)$ & $9(2.8 \%)$ & - & \multirow[t]{2}{*}{324} & \multirow[t]{2}{*}{$<0.0001$} \\
\hline & MDR & $49(15.1 \%)$ & $49(15.1 \%)$ & $21(6.5 \%)$ & $9(2.8 \%)$ & & \\
\hline \multirow[t]{2}{*}{ ESBL } & Not producer & $194(59.9 \%)$ & $78(24.1 \%)$ & $30(9.3 \%)$ & $9(2.8 \%)$ & \multirow[t]{2}{*}{324} & \multirow[t]{2}{*}{$>0.05$} \\
\hline & Producer & $9(2.8 \%)$ & $4(1.2 \%)$ & - & - & & \\
\hline \multirow[t]{2}{*}{ MBL } & Not producer & $13(11.5 \%)$ & $18(15.9 \%)$ & $9(8.0 \%)$ & $3(2.6 \%)$ & \multirow[t]{2}{*}{113} & \multirow[t]{2}{*}{$>0.05$} \\
\hline & Producer & $27(23.9 \%)$ & $29(25.7 \%)$ & $9(8.0 \%)$ & $5(4.4 \%)$ & & \\
\hline \multirow[t]{2}{*}{ Carbapenemase } & Not producer & $36(31.3 \%)$ & $44(38.3 \%)$ & $16(13.9 \%)$ & $7(6.1 \%)$ & \multirow[t]{2}{*}{115} & \multirow[t]{2}{*}{$>0.05$} \\
\hline & Producer & $6(5.2 \%)$ & $3(2.6 \%)$ & $3(2.6 \%)$ & - & & \\
\hline \multirow[t]{2}{*}{$\mathrm{bla}_{\mathrm{NDM}-1}$} & Absent & $18(25.0 \%)$ & $16(22.2 \%)$ & $3(4.2 \%)$ & $2(2.8 \%)$ & \multirow[t]{2}{*}{72} & \multirow[t]{2}{*}{$>0.05$} \\
\hline & Present & $10(13.9 \%)$ & $13(18.1 \%)$ & $7(9.7 \%)$ & $3(4.2 \%)$ & & \\
\hline
\end{tabular}


Table 5

Association between antibiotic resistance, ESBL production, MBL production, biofilm production and bla $\mathrm{NDM}_{-1}$ detection.

\begin{tabular}{|c|c|c|c|c|c|c|c|c|c|c|c|c|}
\hline & ESBL & & & MBL & & & Biofilm & & & NDM & & \\
\hline & $\begin{array}{l}\text { Producers } \\
(\%)\end{array}$ & $\begin{array}{l}\text { Non- } \\
\text { Producers } \\
(\%)\end{array}$ & $\begin{array}{l}\mathrm{P}- \\
\text { value }\end{array}$ & $\begin{array}{l}\text { Producers } \\
(\%)\end{array}$ & $\begin{array}{l}\text { Non- } \\
\text { Producers } \\
(\%)\end{array}$ & $\begin{array}{l}\mathrm{P}- \\
\text { value }\end{array}$ & $\begin{array}{l}\text { Positive } \\
(\%)\end{array}$ & $\begin{array}{l}\text { Negative } \\
(\%)\end{array}$ & $\begin{array}{l}\mathrm{P}- \\
\text { value }\end{array}$ & $\begin{array}{l}\text { Present } \\
(\%)\end{array}$ & $\begin{array}{l}\text { Absent } \\
(\%)\end{array}$ & F \\
\hline $\begin{array}{l}\text { Ampicillin + } \\
\text { Sulbactam }\end{array}$ & $2(1.7 \%)$ & $\begin{array}{l}117 \\
(98.3 \%)\end{array}$ & 0.044 & $\begin{array}{l}57 \\
(65.5 \%)\end{array}$ & $\begin{array}{l}30 \\
(34.48 \%)\end{array}$ & 0.230 & $\begin{array}{l}70 \\
(58.8 \%)\end{array}$ & $\begin{array}{l}49 \\
(41.2 \%)\end{array}$ & $\begin{array}{l}<.001 \\
0.00\end{array}$ & $\begin{array}{l}29 \\
(49.2 \%)\end{array}$ & $\begin{array}{l}30 \\
(50.8 \%)\end{array}$ & $C$ \\
\hline Amikacin & $5(3.4 \%)$ & $\begin{array}{l}140 \\
(96.6 \%)\end{array}$ & 0.856 & $\begin{array}{l}67 \\
(63.2 \%)\end{array}$ & $\begin{array}{l}39 \\
(36.79 \%)\end{array}$ & 0.502 & $\begin{array}{l}82 \\
(56.6 \%)\end{array}$ & $\begin{array}{l}63 \\
(43.4 \%)\end{array}$ & $\begin{array}{l}< \\
0.001\end{array}$ & $\begin{array}{l}32 \\
(47.1 \%)\end{array}$ & $\begin{array}{l}36 \\
(52.9 \%)\end{array}$ & c \\
\hline Cefotaxim & $13(5.4 \%)$ & $\begin{array}{l}226 \\
(94.6 \%)\end{array}$ & 0.061 & $\begin{array}{l}68 \\
(61.3 \%)\end{array}$ & $\begin{array}{l}43 \\
(38.74 \%)\end{array}$ & 0.701 & $\begin{array}{l}111 \\
(46.4 \%)\end{array}$ & $\begin{array}{l}128 \\
(53.6 \%)\end{array}$ & $\begin{array}{l}< \\
0.001\end{array}$ & $\begin{array}{l}32 \\
(45.7 \%)\end{array}$ & $\begin{array}{l}38 \\
(54.3 \%)\end{array}$ & 1 \\
\hline Cefepime & $12(5.0 \%)$ & $\begin{array}{l}229 \\
(95.0 \%)\end{array}$ & 0.235 & $\begin{array}{l}68 \\
(61.3 \%)\end{array}$ & $\begin{array}{l}43 \\
(38.74 \%)\end{array}$ & 0.701 & $\begin{array}{l}108 \\
(44.8 \%)\end{array}$ & $\begin{array}{l}133 \\
(55.2 \%)\end{array}$ & $\begin{array}{l}<.001 \\
0.001\end{array}$ & $\begin{array}{l}32 \\
(45.7 \%)\end{array}$ & $\begin{array}{l}38 \\
(54.3 \%)\end{array}$ & 1 \\
\hline Ceftriaxone & $9(4.2 \%)$ & $\begin{array}{l}204 \\
(95.8 \%)\end{array}$ & 1.000 & $\begin{array}{l}68 \\
(61.3 \%)\end{array}$ & $\begin{array}{l}42 \\
(38.18 \%)\end{array}$ & 0.713 & $\begin{array}{l}105 \\
(49.3 \%)\end{array}$ & $\begin{array}{l}108 \\
(50.7 \%)\end{array}$ & $\begin{array}{l}<.001 \\
0.01\end{array}$ & $\begin{array}{l}32 \\
(45.7 \%)\end{array}$ & $\begin{array}{l}38 \\
(54.3 \%)\end{array}$ & 1 \\
\hline Ceftazidim & $12(5.1 \%)$ & $\begin{array}{l}223 \\
(94.9 \%)\end{array}$ & 0.189 & $\begin{array}{l}68 \\
(61.3 \%)\end{array}$ & $\begin{array}{l}43 \\
(38.74 \%)\end{array}$ & 0.701 & $\begin{array}{l}112 \\
(47.7 \%)\end{array}$ & $\begin{array}{l}123 \\
(52.3 \%)\end{array}$ & $\begin{array}{l}< \\
0.001\end{array}$ & $\begin{array}{l}32 \\
(45.7 \%)\end{array}$ & $\begin{array}{l}38 \\
(54.3 \%)\end{array}$ & 1 \\
\hline Piperacillin & $6(2.8 \%)$ & $\begin{array}{l}207 \\
(97.2 \%)\end{array}$ & 0.222 & $\begin{array}{l}70 \\
(63.1 \%)\end{array}$ & $\begin{array}{l}41 \\
(36.94 \%)\end{array}$ & 0.278 & $\begin{array}{l}106 \\
(49.8 \%)\end{array}$ & $\begin{array}{l}107 \\
(50.2 \%)\end{array}$ & $\begin{array}{l}< \\
0.001\end{array}$ & $\begin{array}{l}33 \\
(45.8 \%)\end{array}$ & $\begin{array}{l}39 \\
(54.2 \%)\end{array}$ & 1 \\
\hline Ciprofloxacin & $5(3.1 \%)$ & $\begin{array}{l}157 \\
(96.9 \%)\end{array}$ & 0.571 & $\begin{array}{l}68 \\
(62.4 \%)\end{array}$ & $\begin{array}{l}41 \\
(37.61 \%)\end{array}$ & 1.000 & $\begin{array}{l}93 \\
(57.4 \%)\end{array}$ & $\begin{array}{l}69 \\
(42.6 \%)\end{array}$ & $\begin{array}{l}<.001 \\
0 .\end{array}$ & $\begin{array}{l}32 \\
(45.7 \%)\end{array}$ & $\begin{array}{l}38 \\
(54.3 \%)\end{array}$ & 1 \\
\hline Imipenem & $2(1.8 \%)$ & $\begin{array}{l}112 \\
(98.2 \%)\end{array}$ & 0.219 & $\begin{array}{l}70 \\
(62.5 \%)\end{array}$ & $\begin{array}{l}42 \\
(37.50 \%)\end{array}$ & 0.805 & $\begin{array}{l}75 \\
(65.8 \%)\end{array}$ & $\begin{array}{l}39 \\
(34.2 \%)\end{array}$ & $\begin{array}{l}< \\
0.001\end{array}$ & $\begin{array}{l}33 \\
(45.8 \%)\end{array}$ & $\begin{array}{l}39 \\
(54.2 \%)\end{array}$ & 1 \\
\hline
\end{tabular}

\section{Discussion}

Acinetobacter is one of the notorious nosocomial pathogen and its tendency to develop resistance against the antimicrobial drugs is important at any health care facility, particularly from effective patient management and hospital infection control and prevention perspectives. Among five Acinetobacter species, Acb (Acinetobacter calcoaceticus-A. baumannii) complex was predominating species (51.5\%) in this study which was comparable to finding by Gupta et al. 2015 from India which documented Acb complex (72\%), A. Iwoffii (14\%), A. haemolyticus (12\%), A. junii (1\%), A. radioresistens (1\%) [20]. About 12\% of isolates were obtained from ICU, which was comparable to previous report by Siwakoti et al. 2018 [21]. This indicates that ICU might be the important location for colonization and survival of Acinetobacter in a hospital environment [22]. ICU patients usually require prolonged hospital stay, need repeated invasive procedures, are under various devises for life support and frequently receive treatment with broad spectrum antimicrobials. In this study, majority of Acinetobacter were from blood (25.9\%) which was consistent with previously reported (25\%) by Shrestha et al. 2013 [23].

Resistance to cefepime (74.4\%) and cefotaxime (73.8\%) was detected in $74.4 \%$ and $73.8 \%$ of isolates respectively, followed by ceftazidime (72.5\%), ceftriaxone (65\%) and piperacillin 65\%. Except piperacillin, antibiotic resistance patterns were comparable with that reported by Shrestha et al. 2013 in Nepal as ceftazidime (84\%), ceftriaxone (66\%), and piperacillin (96\%) [23]. In addition, Amatya et al. 2015 documented resistance towards ceftazidime (81\%), cefotaxime (67.3\%) and ceftriaxone (69.3\%) [24]. In another study by Yadav et al. 2017 reported highest resistant to ceftazidime (80\%) and piperacillin (80\%) [25]. We found that the isolates resistance to amikacin were $44.7 \%$ and to ciprofloxacin $50.0 \%$ which was consistent with report by Shrestha et al. [23]. In addition, Amatya et al. 2015 had documented amikacin and ciprofloxacin resistance as $56.7 \%$ and $68.7 \%$ respectively [24].

Although carbapenem was the first line drug against Acinetobacter infection in the late 1990s, carbapenem resistant strains are increasingly reported worldwide in recent days [6]. Our finding on imipenem resistance of 35.2\% (114/324) was inconsistent with Amatya et al. 2015 (47.3\%) and Gupta et al. 2015 (21.2\%). In contrast to our finding, Parajuli et al. 2017 reported $86.4 \%$ imipenem resistance. Among the ICU isolates, $42.5 \%$ were sensitive to ampicillin + sulbactam and imipenem \%. However, Shakibaie et al. 2012 had contrasting finding that Acinetobacter species were resistant to almost all antibiotics routinely used in the ICUs of their hospital [26].

In this study, 128 (39.5\%) isolates were determined as multi-drug resistant (MDR) which was consistent with Gupta et al. 2015 (39.6\%) [20]. Out of 128 MDR isolates, we found that Acb complex were 111 (86.7\%) MDR strains which was higher than $71 \%$ reported by Amatya et al. 2015 [24]. Acinetobacter appears to have a propensity to develop antibiotic resistance extremely rapidly, as a consequence of prolong antibiotic exposure. Hence, the increasing trends of Acinetobacter MDR strains were reported globally [27].

In the present study, $235(72.5 \%)$ strains were ceftazidime resistant and $13(4.0 \%)$ of them had shown ESBL production by double disc synergy test. Our result on ESBL Acinetobacter isolates was comparable with 7\% reported by Marzieh et al. 2015 [28]. In contrast to this study, Gupta et al. 2015 found $31.5 \%$ of ESBL producing isolates. Since, the antimicrobial susceptibility pattern could be variable depending on several factors, the surveillance studies have crucial role in deciding the therapy against Acinetobacter infections [20]. Among MDR isolates in this study, 10.7\% had demonstrated the carbapenemase production phenotype. Amjad et al. 2011 reported 12\% carbapenemase producers by Modified Hodge test [29] and Gupta et al. 2015 had reported 14.4\% metallo $\beta$ lactamases (MBL) producer isolates by combined disc diffusion test [20]. 
The gold standard for the identification of carbapenemase production and detection of bla $\mathrm{NDM}-1_{1}$ gene is PCR assay [30]. Moreover, other assay such as Loop mediated isothermal amplification [31] has been developed for the detection of bla $\mathrm{NDM}_{-1}$ gene. In this study, NDM producing Acinetobacter isolates was $10.2 \%$ (33/324) which was consistent with reports by Devkota et al. 2017 (12.8\%) [32]. The evidence of Acinetobacter with presence of bla ${ }_{\text {NDM-1 }}$ gene had already been reported worldwide [33,34]. In this study, 91\% NDM producers were resistant to second and third generation cephalosporins. Moreover, 25.8\% (33/128) bla $_{\mathrm{NDM}-1}$ gene containing isolates had also MDR phenotype. However, we found Imipenem was the most effective antibiotic in this study as $35.2 \%$ imipenem resistance.

The biofilm forming phenotype of Acinetobacter was determined by 96 -well plate assay and we found $37.3 \%$ of isolates were biofilm former which was inconsistent with reported 73.7\% by Babapour et al. 2016 [35]. Moreover, $65.3 \%$ of biofilm forming isolates had significantly associated to multi-drug resistant phenotype. However, other study had shown inconsistent biofilm producer to our finding, 92\% reported by Babapour et al. 2016 [35] and $90.3 \%$ reported by Badave et al. 2015 [6]. We found that isolates with highest biofilm producer was Acb complex (77.7\%) which was marginally higher than $60 \%$ reported by Yadav et al. 2017. This disagreement may be due to the variation in the nature of clinical isolates from different geographical locations. Biofilm forming isolates found mostly samples from medical devices (37.2\%) followed by pus (29.8\%) which was consistent with previous studies [36,37]. In addition, the biofilm forming isolates were predominating in ICU (64.4\%) followed by wards (31.1\%) which was consistent with other studies [38]. Among the biofilm formers in this study, we found resistance to imipenem 62.0\% (75/121) which was higher than $46.7 \%$ reported by Yadav et al 2017 [25]. Moreover, association between biofilm producer and imipenem has also shown by Chaudhary et al. 2017 [39]. Nahar et al. 2013 has reported that the clinical Acinetobacter isolates from ICU had both phenotype biofilm producers and multi-drug resistant [40]. However, a few variable results are seen in several studies due to different scenario that might be due to difference in geography, arrangement of specimens in the study groups, condition and use of antibiotic.

The data from this study demonstrates that Acinetobacter species are resistant to many available antimicrobial agents making this nosocomial pathogens one of the most significant microbial challenges to control in future.

\section{Conclusion}

The clinical isolates of Acinetobacter in our setting were multi-drug resistant and biofilm former as revealed by the present study. In addition, the biofilm formation could be the potential marker to determine the multi-drug resistant (MDR) phenotype. These isolates have been proven to cause nosocomial infection in health care settings. Therefore, a consolidated effort by all concerned health care providers strict implementation of infection prevention and control activities is recommended to reduce the burden of antimicrobial resistance.

\section{Methods}

A total of 324 Acinetobacter species isolates obtained from various clinical specimens, submitted to Department of Microbiology, B. P. Koirala Institute of Health Sciences (BPKIHS) for culture and sensitivity were included. The study was conducted from September 2017 to August 2018 . Ethical approval was obtained from the Institutional Review Committee of BPKIHS.

\section{Identification of Acinetobacter species}

Direct microscopic examination of Gram stained smear of all the samples except blood was performed. Inoculation of the samples onto appropriate culture media, incubation, and detection of growth after the recommended duration was done by standard microbiological techniques [8]. Suspected smooth, opaque colonies on blood agar corresponding non lactose fermenting colonies on MacConkey and on CLED agar plates were presumed as Acinetobacter and processed further. Species identification of the genus Acinetobacter was done by several biochemical tests [9].

\section{Antimicrobial Susceptibility test}

Antibiotic sensitivity test was done on Mueller Hinton Agar (MHA) by Kirby Bauer disc diffusion method recommended by clinical and Laboratory Standard Institute (CLSI) guidelines [8]. Escherichia coli ATCC 25922 was used as a control and tested along with the test strain. Antimicrobials drugs tested were Piperacillin $(100 \mu \mathrm{g})$, ceftazidime $(30 \mu \mathrm{g})$, ceftriaxone $(30 \mu \mathrm{g})$, cefotaxime $(30 \mu \mathrm{g})$, cefepime $(30 \mu \mathrm{g})$, ciprofloxacin $(5 \mu \mathrm{g})$, imipenem $(10 \mu \mathrm{g})$ amikacin $(30 \mu \mathrm{g})$, ampicillin + sulbactam $(10 / 10 \mu \mathrm{g})$. Resistances to at least one antimicrobial agent in $\geq 3$ antimicrobial classes were considered as multi-drug resistance (MDR).

\section{Detection of ESBL phenotype}

According to the CLSI guidelines, the probable ESBL producing isolate had zone of inhibition for ceftazidime $(30 \mu \mathrm{g}) \leq 22 \mathrm{~mm}$ and cefotaxime ( $30 \mu \mathrm{g}) \leq$ $27 \mathrm{~mm}$ [8]. In order to confirm ESBL production, ceftazidime $(30 \mu \mathrm{g})$ and ceftazidime + clavulanate $(30 / 10 \mu \mathrm{g})$ disc were placed in Acinetobacter culture. Zone of inhibition were compared with the ceftazidime and cefotaxime discs alone and compared with the combined ceftazidime + clavulanate disc. An enhanced zone of diameter of $\geq 5 \mathrm{~mm}$ in combination with clavulanate confirmed isolates as ESBL.

\section{Detection of metallo- $\beta$-lactamase enzyme (MBL) phenotype}

\section{a. Combined disc diffusion test}


Combined disc diffusion test was employed to determine the MBL producing phenotype in Acinetobacter. On MHA plate lawn culture of Acinetobacter, imipenem disc $(10 \mu \mathrm{g})$ and imipenem disc with $10 \mu \mathrm{l}$ of $0.5 \mathrm{M}$ EDTA were applied $20 \mathrm{~mm}$ apart from center to center. Isolate demonstrating zone of inhibition of more than $7 \mathrm{~mm}$ around the imipenem-EDTA disc than imipenem disc alone was considered as MBL producer [10].

\section{b. Carbapenemase production test}

Phenotypic detection of carbapenemase producing MDR Acinetobacter was determined by Modified Hodge Test [8]. First, overnight broth culture of Escherichia coli ATCC 25922 was adjusted to 0.5 McFarland standards, and spread in a dried surface of Mueller Hinton agar (MHA) plate by sterile cotton swab. After brief drying, a $10 \mu \mathrm{g}$ imipenem (IMP) disc was placed at the center of the plate and tested strains were streaked from center to periphery of the plate in four different directions. Following overnight incubation at $37^{\circ} \mathrm{C}$, carbapenemase positive isolates showed the distorted zone of inhibition, a 'clove leaf pattern' was observed due to carbapenemase production by isolate.

\section{Molecular detection of bla $\mathrm{NDM}_{1}$ gene}

New Delhi metallo-beta-lactamase- $1\left(\right.$ bla $\left._{\text {NDM }-1}\right)$ is a novel MBL that confers resistance to all $\beta$-lactam antibiotics with the exception of aztreonam. In this study, the multi-drug resistant organisms were selected to detect bla ${ }_{\text {NDM -1 }}$ gene by conventional PCR [11].

\section{DNA extraction of bacterial isolates}

The overnight broth cultures were centrifuged at 3,500 rpm for 10 minutes at $4{ }^{\circ} \mathrm{C}$. Then, the supernatant was discarded and the pellet was washed twice with $5 \mathrm{ml}$ phosphate buffered saline (PBS) followed by centrifugation. The pellet was re-suspended in $1 \mathrm{ml} \mathrm{PBS}$ and centrifuged at 10,000 rpm for $10 \mathrm{minutes}$ at $4{ }^{\circ} \mathrm{C}$. Finally, the supernatant was discarded and the remaining pellet was stored at $-20^{\circ} \mathrm{C}$ till assayed. [12].

The pellet was dissolved in $200 \mu \mathrm{L}$ of TE buffer. Then, the mix was heated at $100{ }^{\circ} \mathrm{C}$ for 10 minutes with shaking and rapidly transferred to ice-bath for 10 min. Centrifugation was done at $13,000 \mathrm{rpm}$ for 30 seconds at $4{ }^{\circ} \mathrm{C}$. Finally, $100 \mu \mathrm{L}$ of supernatant DNA was transferred to new tube. The concentration and purity of the DNA were measured by Nano drop 2000 spectrophotometer (Thermofisher).

\section{Polymerase Chain Reaction (PCR) for detection of bla $\mathrm{NDM}_{-1}$}

The bla $\mathrm{NDM}_{-1}$ gene specific PCR was performed to detect bla $\mathrm{NDM}_{-1}$. PCR master mix was prepared in $25 \mu \mathrm{L}$ final volume which constituted $1 \mathrm{X}$ Qiagen PCR buffer, $2 \mathrm{mM} \mathrm{MgCl} 2,0.1 \mathrm{mg} / \mathrm{ml} \mathrm{BSA}, 0.2 \mathrm{mM}$ of dNTP mix, $0.8 \mu \mathrm{M}$ of each primer NDM1-F (5'-CAGCACACTTCCTATCTC-3') and NDM1-R (5'-

CCGCAACCATCCCCTCTT-3'), 0.5 Unit of Taq polymerase and $2 \mu \mathrm{L}$ of DNA template. PCR amplification was done in Eppendorf Mastercycle ProS (Eppendorf, Germany) with (i) initial denaturation at $95^{\circ} \mathrm{C}$ for 5 minutes; (ii) 35 cycles of denaturation at $94{ }^{\circ} \mathrm{C}$ for 30 seconds, $55^{\circ} \mathrm{C}$ for 30 seconds, then $72{ }^{\circ} \mathrm{C}$ for 30 seconds; and (iii) a final extension at $72^{\circ} \mathrm{C}$ for 10 minutes. PCR water was used as a negative control, and the DNA from bacterial culture with bla ${ }_{\mathrm{NDM}}-1$ PCR positive result was considered as a positive control. After electrophoresis of amplified DNA in $2 \%$ agarose gel at $5 \mathrm{~V} / \mathrm{cm}$ and ethidium bromide staining, the DNA band was visualized with UV exposure [13]. The sample was identified as bla $\mathrm{NDM}_{-1}$ PCR positive result if DNA band of 300 bp was seen in gel.

\section{Detection of Biofilm formation}

Detection of biofilm formation was performed by the standard laboratory methods described elsewhere [14-17]. The bacterial isolates were grown overnight at $37^{\circ} \mathrm{C}$ in $5 \mathrm{ml}$ of tryptic soy broth (TSB). Methicillin-sensitive Staphylococcus aureus (MSSA) ATCC-25923 and P. aeruginosa ATCC-27853 were used as negative and positive controls, respectively. Each well of a 96 -well flat-bottomed plate was filled with $200 \mu \mathrm{L}$ of the overnight culture broth ( $0.5 \mathrm{McFarland}$ standard diluted with $1 \%$ glucose + TSB). The plates were covered with lid and incubated aerobically for 24 hours at $37^{\circ} \mathrm{C}$. After incubation, the content of each well was removed and washed three times with $300 \mu \mathrm{L}$ sterile phosphate-buffered saline (PBS; pH 7.2) in order to remove freely floating bacteria.

Following every washing, the plates were drained in an inverted position. Adherent bacteria was fixed with $150 \mu \mathrm{L}$ of methanol for 20 min, the $96-$ well plate was emptied by simple flicking, and it was left to air dry overnight at room temperature. The adherent biofilm layer formed in each 96 -well plate well was stained with $150 \mu \mathrm{L}$ of $2 \%$ Hucker crystal violet for $15 \mathrm{~min}$. Excess stain was rinsed off by placing the 96 -well plate under the running tap water until the release of stain stop. The 96 -well plate was air dried at room temperature. Then, $150 \mu \mathrm{L}$ of $95 \%$ ethanol was gently added in each well of microtiter-plate in order to cell resuspension. Again the plate was incubated at room temperature for 30 min without shaking. The optical density (OD) of each solution in well stained with crystal violet was measured at $570 \mathrm{~nm}$ using a microtiter-plate reader.

Interpretation of OD measurements: The average OD values were calculated for all tested strains and negative controls. The cut-off value (ODc) was calculated as three standard deviations (SD) above the mean OD of negative control. ODc $=$ average OD of negative control $+(3 \times S D$ of negative control). Strains were divided into four categories which are based upon OD values: (a) $O D \leq O D c=$ no biofilms producer, (b) $O D c<O D \leq 2 \times O D c=w e a k$ biofilm production (+), (c) $2 \times \mathrm{ODC}<\mathrm{OD} \leq 4 \times \mathrm{ODc}=$ moderate biofilm production $(++)$, and (d) $4 \times \mathrm{ODC}<\mathrm{OD}=$ strong biofilm production $(+++)$.

\section{Analysis}

Data were entered in MS Excel worksheet and statistical analysis was done by using R package [18]. The principle component analysis among the several factors was done by using "prcomp" function of R stat package and visualization of the plot was demonstrated by ggbiplot package [19].

\section{Declarations}


Ethics approval and consent to participate

Ethical approval was obtained from Institutional Review Committee (IRC), B. P. Koirala Institute of Health Sciences, Dharan, Sunsari, Nepal

Code No IRC/761/074/075.

Consent to participate: written informed consent was obtained from each patient.

Consent for publication

Not applicable.

Availability of data and materials

Yes, the data of the analysis are available upon the request from the corresponding author or head, department of Microbiology

(hod.microbiology@bpkihs.edu), BP Koirala Institute of Health Sciences, Dharan, Nepal.

Competing Interest

We declare that we have no competing interests.

Funding

Not applicable.

Author's Contributions

Conceptualization: MK, NRB, BK

Data curation: MK, TP, KR

Formal analysis: MK, BK

Funding acquisition: NRB, BK

Investigation: MK, KR

Methodology: MK, NRB, KR

Resources: MK, BK, NRB

Software: MK, KR

Supervision: BK, NRB

Validation: NRB, BK, TP, KR

Visualization: $\mathrm{MK}, \mathrm{KR}$

Writing- original draft: $M K, K R$

Writing- reviewing \& editing: NRB, BK

Acknowledgements

We wish to express our kind gratitude to all the technicians, students at Microbiology Laboratory (B. P. Koirala Institute of Health Sciences) for their cooperation and kind support for this study.

\section{Abbreviations}

bla $_{\text {NDM-1 }}$

New Delhi metallo-beta-lactamase-1

ICU

Intensive Care Unit

OPD

Out Patient Department

NICU

Neonatal Intensive Care Unit

ER

Emergency

ET-TUBE

Endotracheal-Tube

\section{References}

1. Dijkshoorn L, Nemec A, Seifert H. An increasing threat in hospitals: multidrug-resistant Acinetobacter baumannii. Nat Rev Microbiol. $2007 ; 5(12): 939$ - 51. doi:nrmicro1789 [pii];10.1038/nrmicro1789 [doi]

2. Falagas ME, Kopterides P, Siempos II. Attributable mortality of Acinetobacter baumannii infection among critically ill patients. Clin Infect Dis. 2006;43(3):389 - 90. doi:CID39609 [pii];10.1086/505599 [doi]

3. Rodriguez-Bano J, Marti S, Soto S, Fernandez-Cuenca F, Cisneros JM, Pachon J, Pascual A, Martinez-Martinez L, McQueary C, Actis LA, Vila J. Biofilm formation in Acinetobacter baumannii: associated features and clinical implications. Clin Microbiol Infect. 2008;14(3):276-8. doi:S1198-743X(14)61248-9 [pii];10.1111/j.1469-0691.2007.01916.x [doi]

4. Costerton JW, Stewart PS, Greenberg EP. Bacterial biofilms: a common cause of persistent infections. Science. 1999;284(5418):1318-22.

doi:10.1126/science.284.5418.1318

5. Peleg AY, Seifert H, Paterson DL. Acinetobacter baumannii: emergence of a successful pathogen. Clin Microbiol Rev. 2008;21(3):538 - 82. doi:21/3/538 [pii];10.1128/CMR.00058- 07 [doi]

6. Manchanda V, Sanchaita S, Singh NP. Symposium on infectious agents in a multidrug resistant globe. J Global Infectious Diseases. 2010;2(3):291-304. 
7. Badave GK, Kulkarni D. Biofilm Producing Multidrug Resistant Acinetobacter baumannii: An Emerging Challenge. J Clin Diagn Res. 2015;9(1):DC08-DC10. doi:10.7860/JCDR/2015/11014.5398 [doi]

8. CLSI. Performance standard for antimicrobial susceptibility testing; twenty-fifth infomation supplement. CLSI document M100-S25. Wayne, PA: Clinical and Laboratory Standards Institute; 2015.

9. Winn WC, Koneman EW. Koneman's color atlas and textbook of diagnostic microbiology. 6 Ed. ed. Phladelphia: Lippincott Williams \& Wilkins; 2006. 10. Yong D, Lee K, Yum JH, Shin HB, Rossolini GM, Chong Y. Imipenem-EDTA disk method for differentiation of metallo-beta-lactamase-producing clinical isolates of Pseudomonas spp. and Acinetobacter spp. J Clin Microbiol. 2002;40(10):3798 - 801. doi:10.1128/jcm.40.10.3798-3801.2002

11. Liu W, Zou D, Li Y, Wang X, He X, Wei X, Shao C, Li X, Shang W, Yu K, Liu D, Li Y, Guo J, Yin Z, Yuan J. Sensitive and rapid detection of the new Delhi metallobeta-lactamase gene by loop-mediated isothermal amplification. J Clin Microbiol. 2012;50(5):1580-5. doi:JCM.06647-11 [pii];10.1128/JCM.06647-11 [doi] 12. Millar BC, Jiru X, Moore JE, Earle JA. A simple and sensitive method to extract bacterial, yeast and fungal DNA from blood culture material. J Microbiol Methods. 2000;42(2):139 - 47. doi:S0167-7012(00)00174-3 [pii]

13. Sambrook J, Russell RW. Molecular cloning: a laboratory manual. 3 ed. New York: Cold Spring Harbor Laboratory Press; 2001.

14. Christensen GD, Simpson WA, Bisno AL, Beachey EH. Adherence of slime-producing strains of Staphylococcus epidermidis to smooth surfaces. Infect Immun. 1982;37(1):318 - 26. doi:PMID:6179880

15. Toledo-Arana A, Valle J, Solano C, Arrizubieta MJ, Cucarella C, Lamata M, Amorena B, Leiva J, Penades JR, Lasa I. The enterococcal surface protein, Esp, is involved in Enterococcus faecalis biofilm formation. Appl Environ Microbiol. 2001;67(10):4538-45. doi:10.1128/aem.67.10.4538-4545.2001

16. Basson A, Flemming LA, Chenia HY. Evaluation of adherence, hydrophobicity, aggregation, and biofilm development of Flavobacterium johnsoniae-like isolates. Microb Ecol. 2008;55(1):1-14. doi:10.1007/s00248-007-9245-y [doi]

17. Stepanovic S, Vukovic D, Hola V, Di BG, Djukic S, Cirkovic I, Ruzicka F. Quantification of biofilm in microtiter plates: overview of testing conditions and practical recommendations for assessment of biofilm production by staphylococci. APMIS. 2007;115(8):891-9. doi:APMapm_630 [pii];10.1111/j.1600-

0463.2007.apm_630.x [doi]

18. R Core Team. R: A language and environment for statistical computing. R Foundation for Statistical Computing, Vienna, Austria. 2014. http://www.Rproject.org. Accessed 12 Aug 2019.

19. Vincent Qv. ggbiplot: A ggplot2 based biplot. 2011. R package version 0.55. http://github.com/vqv/ggbiplot. Accessed 12 Aug 2019.

20. Gupta N, Gandham N, Jadhav S, Mishra RN. Isolation and identification of Acinetobacter species with special reference to antibiotic resistance. J Nat Sci Biol Med. 2015;6(1):159 - 62. doi:10.4103/0976-9668.149116 [doi];JNSBM-6-159 [pii]

21. Siwakoti S, Subedi A, Sharma A, Baral R, Bhattarai NR, Khanal B. Incidence and outcomes of multidrug-resistant gram-negative bacteria infections in intensive care unit from Nepal- a prospective cohort study. Antimicrob Resist Infect Control. 2018;7(114. doi:10.1186/s13756-018-0404-3 [doi];404 [pii] 22. Vincent JL, Rello J, Marshall J, Silva E, Anzueto A, Martin CD, Moreno R, Lipman J, Gomersall C, Sakr Y, Reinhart K. International study of the prevalence and outcomes of infection in intensive care units. JAMA. 2009;302(21):2323-9. doi:302/21/2323 [pii];10.1001/jama.2009.1754 [doi]

23. Shrestha M, Khanal B. Acinetobacter species: phenotypic characterization and antimicrobial resistance. J Nobel Medical College. 2013;2(3):43 - 8.

24. Amatya R, Acharya D. Prevalence of tigecycline resistant multidrug resistant Acinetobacter calcoaceticus-Acinetobacter baumannii complex from a tertiary care hospital in Nepal. Nepal Med Coll J. 2015;17(1-2):83-6.

25. Yadav SK, Lekhak B, Upreti MK, Lekhak S. Antibiogram of biofilm producer Acinetobacter isolates from different clinical specimens. GoldenGate Journal of Science \& Technology. 2017;3:68-73.

26. Shakibaie MR, Adeli S, Salehi MH. Antibiotic resistance patterns and extended-spectrum beta-lactamase production among Acinetobacter spp. isolated from an intensive care Unit of a hospital in Kerman, Iran. Antimicrob Resist Infect Control. 2012;1(1):1. doi:2047-2994-1-1 [pii];10.1186/2047-2994-1-1 [doi] 27. Bassetti M, Peghin M, Vena A, Giacobbe DR. Treatment of Infections Due to MDR Gram-Negative Bacteria. Front Med (Lausanne). $2019 ; 6$ (74. doi:10.3389/fmed.2019.00074 [doi]

28. Safari M, Mozaffari Nejad AS, Bahador A, Jafari R, Alikhani MY. Prevalence of ESBL and MBL encoding genes in Acinetobacter baumannii strains isolated from patients of intensive care units (ICU). Saudi J Biol Sci. 2015;22(4):424-9. doi:10.1016/j.sjbs.2015.01.004 [doi];S1319-562× (15)00005 - 4 [pii]

29. Amjad A, Mirza I, Abbasi S, Farwa U, Malik N, Zia F. Modified Hodge test: A simple and effective test for detection of carbapenemase production. Iran J Microbiol. 2011;3(4):189- 93.

30. Poirel L, Dortet L, Bernabeu S, Nordmann P. Genetic features of blaNDM-1-positive Enterobacteriaceae. Antimicrob Agents Chemother. 2011;55(11):5403-7. doi:AAC.00585-11 [pii];10.1128/AAC.00585- 11 [doi]

31. Rathinasabapathi P, Hiremath DS, Arunraj R, Parani M. Molecular Detection of New Delhi Metallo-Beta-Lactamase-1 (NDM-1) Positive Bacteria from Environmental and Drinking Water Samples by Loop Mediated Isothermal Amplification of bla NDM-1. Indian J Microbiol. 2015;55(4):400-5.

doi:10.1007/s12088-015-0540-x [doi];540 [pii]

32. Devkota SP, Sharma S, Bhatta DR, Paudel A, Sah AK, Kandel BP. Prevalence of the blaNDM gene among metallo-beta-lactamase-producing Gram-negative isolates from western Nepal. J Glob Antimicrob Resist. 2018;12(3-4. doi:S2213-7165(17)30214-X [pii];10.1016/j.jgar.2017.11.003 [doi]

33. Bushnell G, Mitrani-Gold F, Mundy LM. Emergence of New Delhi metallo-beta-lactamase type 1-producing enterobacteriaceae and non-enterobacteriaceae: global case detection and bacterial surveillance. Int J Infect Dis. 2013;17(5):e325-e333. doi:S1201-9712(12)01318-5 [pii];10.1016/j.jid.2012.11.025 [doi] 34. Dortet L, Poirel L, Nordmann P. Worldwide dissemination of the NDM-type carbapenemases in Gram-negative bacteria. Biomed Res Int. $2014 ; 2014(249856$. doi:10.1155/2014/249856 [doi]

35. Babapour E, Haddadi A, Mirnejad R, Angaji S, Amirmozafari N. Biofilm formation in clinical isolates of nosocomial Acinetobacter baumannii and its relationship with multidrug resistance. Asian Pacific J Tropical Biomedicine. 2016;6(6):528 - 33.

36. Pour NK, Dusane DH, Dhakephalkar PK, Zamin FR, Zinjarde SS, Chopade BA. Biofilm formation by Acinetobacter baumannii strains isolated from urinary tract infection and urinary catheters. FEMS Immunol Med Microbiol. 2011;62(3):328 - 38. doi:10.1111/j.1574-695X.2011.00818.x [doi]

37. Greene C, Wu J, Rickard AH, Xi C. Evaluation of the ability of Acinetobacter baumannii to form biofilms on six different biomedical relevant surfaces. Lett Appl Microbiol. 2016;63(4):233-9. doi:10.1111/lam.12627 [doi]

Page 9/11 
38. von EC, Jansen B, Kohnen W, Becker K. Infections associated with medical devices: pathogenesis, management and prophylaxis. Drugs. 2005;65(2):179214. doi:6523 [pii];10.2165/00003495-200565020-00003 [doi]

39. Chaudhary A, Routray A, Madhavan R. Evaluation of biofilm production in Acinetobacter baumannii with reference to imipenem resistance. Int J Scientific and Research Publication. 2017;7(12):732-7.

40. Nahar A, Anwar S, Miah MR. Association of biofilm fromation with antimicrobial resistance among the Acinetobacter species in a tertiary care hospital in Bangladesh. J Medicine. 2013;14:28-32.

\section{Figures}

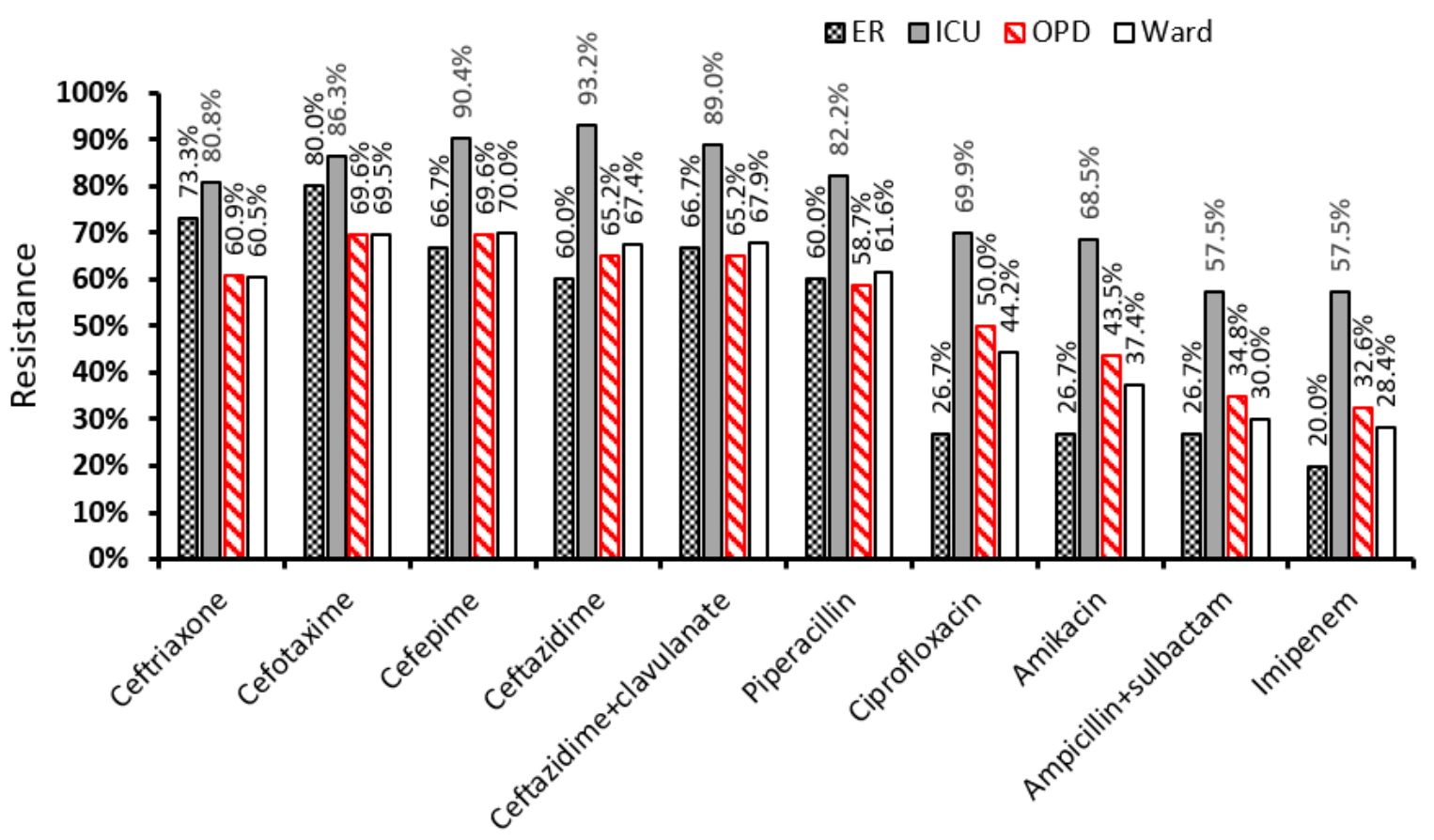

Figure 1

Origin wise distribution of antibiotic resistance in clinical isolates. Note: ER = Emergency, ICU = Intensive Care Unit, OPD = Out Patient Department.

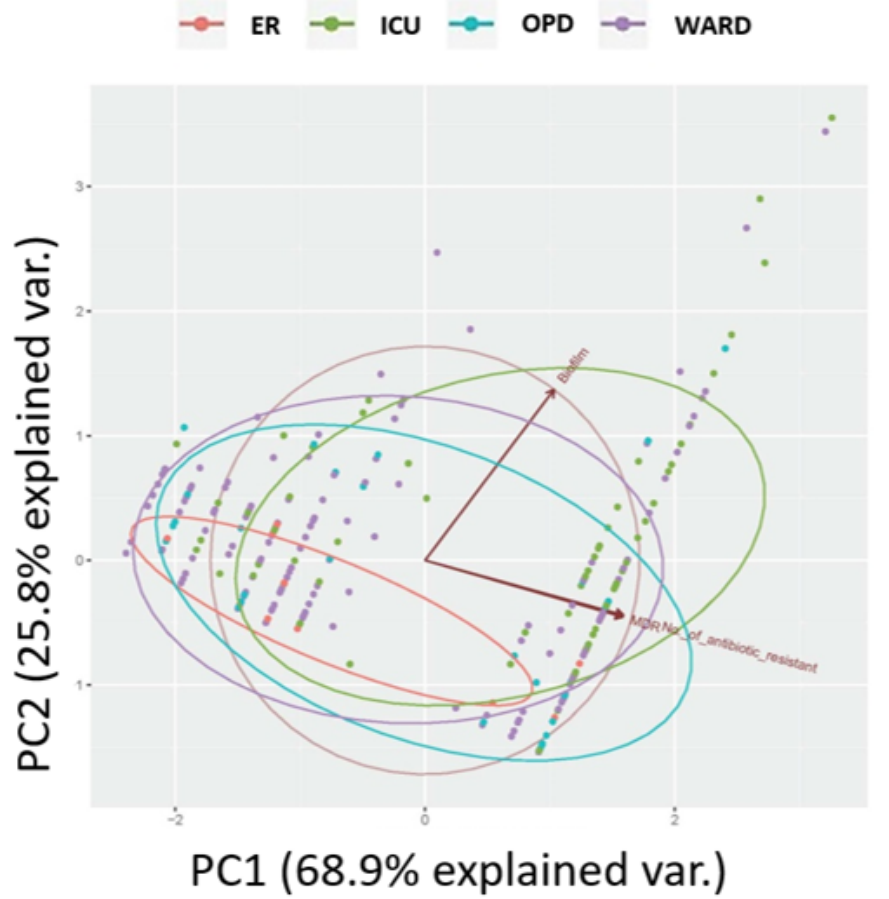

Figure 2 
Principal component analysis (PCA) among isolates' origin, Biofilm formation, MDR and number of antibiotic resistance.

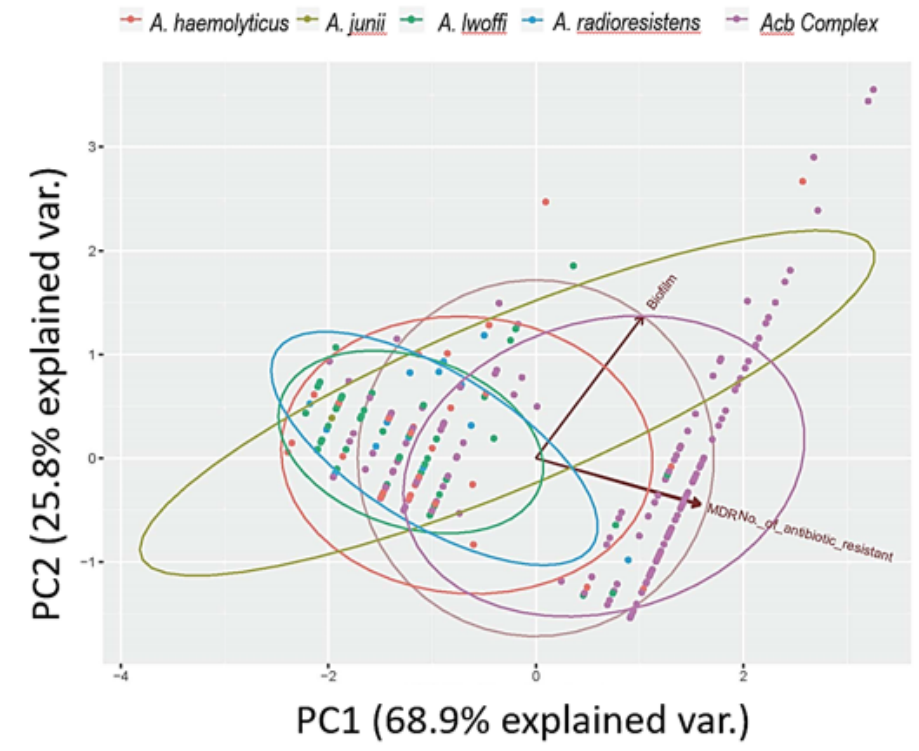

Figure 3

Principle component analysis (PCA) among Acinetobacter species, Biofilm formation, MDR, and number of antibiotic resistance. 